\title{
Festulolium, a century of research and breeding and its increased relevance in meeting the requirements for multifunctional grassland agriculture
}

\author{
M.W. HUMPHREYS ${ }^{1 *}$ and Z. ZWIERZYKOWSKI² \\ Institute of Biological, Environmental and Rural Sciences, Aberystwyth University, \\ SY233EE Aberystwyth, UK \\ Institute of Plant Genetics, Polish Academy of Sciences, PL-60479 Poznan, Poland ${ }^{2}$
}

\begin{abstract}
Festulolium are grasses formed through interspecific hybridisation of ryegrass (Lolium) and fescue (Festuca) species. The Lolium-Festuca genome complex represents a vast array of heterogeneous and largely outbreeding grass species that have evolved, diverged, and adapted, allowing their world-wide colonisation of temperate grasslands. While strategies for grass improvement have focused primarily on intraspecific breeding and, in particular, on the agronomically desirable species Lolium perenne and Lolium multiflorum, a growing interest has emerged in interspecific hybrids as alternatives. The principal driver has been the increased appreciation of the capability of wide hybridisation to extend phenotypic variation beyond the ranges available within a single species. Lolium and Festuca species share complementary and desirable traits, and the prime aim in Festulolium (Festuca $\times$ Lolium) cultivar development has been to combine the agronomic performance of Lolium and the stress resistance of Festuca species. Advances in Festulolium development are timely, and support strategies aimed at delivering a more sustainable future for livestock agriculture, with grass cultivars that are persistent and productive. Festulolium hybrids occur naturally, including examples that demonstrate extreme heterosis with adaptations sufficient to sustain growth in harsh conditions. However, they are largely sterile and their perpetuity depends mainly on vegetative propagation. Synthetic Festulolium hybrids suitable for plant breeding require genome stability and fertility, sufficient for a cost-effective seed production. To this end, suitable amphiploid and introgressionbreeding approaches have been developed. Herein, we provide detailed selected highlights in the research and breeding of Festulolium. In addition, recognising the multifunctional properties of grasslands and the development of enabling technologies that permit their study, we review additional benefits likely to accrue from Festulolium that may mitigate climate change effects and provide valuable ecosystem services.
\end{abstract}

Additional key words: amphiploidy, genome stability, introgression, resitance to harsh conditions.

\section{Introduction}

In an agricultural context, the species deemed most suitable for use as livestock fodder reside within the LoliumFestuca complex and are: Italian ryegrass (L. multiflorum Lam., $2 n=2 x=14$ ), perennial ryegrass (Lolium perenne L., $2 n=2 x=14)$, meadow fescue ( $F$. pratensis Huds., $2 n=2 x=14$ ), and tall fescue (F. arundinacea Schreb., $2 n=6 x=42)$. These Lolium and Festuca species offer a range of complementary agronomic traits, such as high nutritive value of ryegrasses, and persistency and stress tolerance commonly associated with the fescues (Thomas and Humphreys 1991). These attributes can be combined in interspecific hybrids and genotypes with greatest potential advanced through breeding programmes with novel cultivars later assessed for their suitability for inclusion in agricultural systems.

The Festuca genus contains around 600 species (Cheng et al. 2016) and is the largest within the Poaceae family and comprise a series from diploid $(2 n=2 x=14)$ to dodecaploid $(2 n=12 x=84)$ (Clayton and Renvoize 1986, Loureiro et al. 2007). Species within the Festuca genus are widely distributed and combine a diverse range of edaphic and climatic adaptations. The Lolium genus comprises, in contrast to Festuca, only ten species, and all are diploid $(2 n=2 x=14)$ (Jauhar 1993, Cheng et al. 2015).

Intergeneric hybrids between species of the Lolium and Festuca genera are termed Festulolium and include hybrids

Submitted 3 May 2020, last revision 13 July 2020, accepted 14 July 2020.

Abbreviations: GISH - genomic in situ hybridisation; GM -genetic modification; QTL - quantitative trait locus.

*Corresponding author; e-mail:mkh@aber.ac.uk 
that may have evolved naturally, but also increasing numbers as synthetic hybrid cultivars including some with novel genome combinations, all generated through the use of conventional plant breeding technologies.

Prior to 2004, there were strict limitations to the widespread marketing and commercial use of Festulolium cultivars within the European agricultural context. This was a consequence of certain European Union directives (66/401/EEC and 92/19/EEC), whereby marketing of grass cultivars under the Festulolium label was restricted to just a single Lolium and Festuca species combination. This hybrid, also found naturally, and classified as Festulolium braunii (K. Richter) A. Camus, derives from crosspollination of Lolium multiflorum Lam. (Italian ryegrass), a highly productive biennial forage grass, and Festuca pratensis Huds. (meadow fescue), its close relative, a more resilient perennial species, but inferior to the ryegrass in its forage quality.

Subsequent to 2004, and in recognition that previously EU regulations had prevented commercial exploitation of alternative and promising Lolium spp. $\times$ Festuca spp. hybrids, a more inclusive definition was agreed. This amended EU directive (2004/55/EC) enabled all Lolium/ Festuca species combinations with potential value for use in agriculture to be developed and marketed as Festulolium. The changes arose following research outcomes undertaken as part of an EU FPV Programme funded as SAGES (QLRT 30764). The project included use of a range of alternative species' combinations with traits deemed suitable for crop production tailored to contrasting European locations and growth conditions. SAGES research was undertaken by a consortium of leading Europeanbased Festulolium researchers, supported by commercial partners based in the UK, Poland, France, and Norway, and its objectives endorsed by additional allied EU grass seed companies. The redrafted definition for Festulolium embraces in a much more effective manner, the full range of opportunities presented to plant breeders following access to the vast array of genetic and phenotypic variation present within the Lolium-Festuca genome complex.

The recognition that Lolium and Festuca species hybridise naturally has allowed commercial exploitation of Festulolium to proceed in Europe without the constraints applied to other crops that rely on genetic modification (GM) technologies to introduce or enhance expression by a chosen trait.

For this review, some key highlights are provided in Festulolium research and breeding. However, while in part retrospective, the review aims to highlight some recent novel findings and scopes suggestions for future targets for Festulolium research and breeding. These can be achieved through incorporation of the latest high-throughput genomic-assisted breeding (e.g., Kole et. al. 2015), combined with phenomic technologies to screen target traits (e.g., for improved root architecture and ontogeny; Marshall et al. 2016). Through a targeted "designer-breeding" approach, specific Lolium/Festuca species combinations can be created, aimed at specific traits deemed appropriate for "climate-smart" strategies relevant to location for intended use and to specific function requirements. For example, the provision of sustainable yields of high-quality fodder will depend on whether the crop has the necessary resilience sufficient to withstand an abiotic stress it is likely to encounter (Humphreys et al. 2012, Macleod et al. 2013). Breeding targets should become more holistic in order to encompass whole ecosystems, and in so doing, agricultural systems can then be developed that provide efficient win/win scenarios (Humphreys et al. 2014a). For example, it is entirely feasible to provide sustainable, healthy, and efficient fodder for livestock, while alongside also mitigating some of the worst scenarios of climate change (e.g., combating incidents of flooding; Macleod et al. 2013). While many of the ecosystem services likely to benefit from cultivation of Festulolium relate to their root/soil interactions, others emanate from their foliar properties and their interactions as feed for livestock. There is growing evidence that certain novel Festulolium hybrids are capable of delivering better efficiencies in protein use by ruminants than currently provided by existing grass cultivars (e.g., Humphreys et al. 2014b, Kamau et al. 2020).

\section{Development of forage grass breeding using Lolium, Festuca, and Festulolium}

The concept that genotypes selected from heterogeneous and primarily obligate outbreeding species should be selected on the basis of their phenotypes, and those having advantageous trait expression be inter-crossed and advanced through plant breeding programmes in cultivar development, dates back a hundred years. The plant breeding approach may have lacked finesse, and has sometimes been described as "crossing the best with the best, and hoping for the best", but nevertheless, it has been largely successful.

With a few exceptions e.g., L. temulentum, and F. microstachys, that as inbreeding species, have largely entered an evolutionary cul de sac, the majority of species within the Lolium/Festuca complex are outcrossing, in unison providing a vast resource of diverse allelic and phenotypic variants. These variants collectively convey alternative edaphic and climatic adaptations which, by incorporating the latest screening technologies, can be selected and advanced in breeding programmes. New high-throughput genotype and phenotype selection technologies provide greater reliability in trait selection across generations. Their use often circumvents costly, lengthy, and frequently unreliable field trials during cultivar development.

Over the years of forage grass breeding, there has been progression in performance, with successive cultivars demonstrating ever-increasing agronomic gain, providing largely cost-effective, healthy, and sustainable livestock fodder. Grassland agriculture frequently does not compete to any significant extent with standard cropping systems as grass cultivars are particularly well adapted to growth on marginal land, areas deemed unsuitable for alternative crop production, such as cereals. In such marginal areas, grasslands provide a vital contribution in the support of 
frequently fragile rural economies. The ryegrasses, and in particular perennial ryegrass (L. perenne) and Italian ryegrass (L. multiflorum), considered optimal providers of forage of high nutritive value for livestock, are unfortunately susceptible to severe winter and/or summer stresses. Where abiotic stresses are encountered regularly, more resilient grass species are often used including timothy (Phleum pratense L.) and cocksfoot (Dactylis glomerata L.). Fescue species may also be used, in particular the broad-leaved fescues such as meadow fescue (F. pratensis Huds.), and tall fescue (F. arundinacea Schreb.), the close relatives of ryegrass (Humphreys et al. 2006b).

The Welsh Plant Breeding Station (WPBS), which in 2019 celebrated its centenary was at the forefront in the development of grass and clover cultivars, with the first perennial ryegrass cv. S23 released in 1931 (Humphreys et al. 2006b). For many subsequent years, equivalent breeding approaches were practised widely across Europe, the Americas, Asia, and Australasia, involving species and hybrids with adaptations tailored to their end-user and location. In general, plant breeding procedures were based on recurrent selection of individual plants or their half-sib families (Humphreys et al. 2006b). Initial advances were accelerated significantly in the UK following the end of the World War II, when the need for food self-sufficiency was recognised as a major driver and was considered essential to future national security (Stapledon and Davies 1948).

As with ryegrass, Festulolium research dates back at least 100 years. Even as long ago as 1790, suggestions were made for possible progenitors for the naturally occurring Festulolium species, Festulolium loliaceum (Hudson) P. Fournier, (Jenkin 1924, 1933). Clearly, from the infancy of grass breeding, researchers recognised the potential value of interspecific Lolium/Festuca hybrids. This view has steadily gained strength, and now is widely accepted (Essad 1964, Thomas and Humphreys 1991). The benefits are particularly evident in situations where it is deemed necessary to extend the range of genetic diversity and plant adaptation beyond that available within a single grass species.

Heterosis has long been recognised as advantageous, and is frequently demonstrated amongst Festulolium hybrids, where it is evident by the plant vigour, competitive capabilities, and adaptations to stresses. In permanent grasslands, triploid and diploid cytotypes of Festulolium loliaceum (L. perenne $\times F$. pratensis) grow well on waterlogged soils where the performance of the parent species was often suboptimal (Gymer and Whittington 1973, Humphreys and Harper 2008). Extreme examples of heterosis have been observed at high altitudes in Alpine meadows where naturally occurring triploid hybrids between $F$. pratensis $(2 x)$ and $F$. pratensis subsp. apennina (De Not.) Hegi (4x) demonstrate remarkable growth and vigour (Boller and Kopecký 2020). Generally, naturally occurring Festulolium hybrids have little or no male or female fertility (Humphreys and Harper 2008, Kopecký et al. 2016), and rely to a large extent on vegetative propagation. Using $F$. pratensis subsp. apennina as an example, a capability to hybridise and to form hybrids with closely-related species growing in their close proximity provides opportunities for novel genome combinations and plants that frequently thrive in harsh mountain habitats where their complementary or additive traits provide them a selective advantage. Over the millennia, events involving Lolium and Festuca species that have generated advantageous genome combinations through species' hybridisation, and provided them a selective advantage, have become fixed, and may further led to speciation. Whilst the Lolium genus comprises only diploid species, the Festuca genus if far larger and more complex, and includes many species that have evolved following interspecific hybridisation. For such species to evolve from interspecific hybrids, it is necessary that they acquire fertility. This was achieved by chromosome doubling, and led to the creation of a polyploid series in the Festuca genus. Chromosome doubling in fescue species is thought to have arisen largely as a consequence of unreduced gametes formed by their constituent parent species, during meiosis (Kopecký et al. 2016). Chromosome doubling within hybrids not only provided fertility, but also enabled advantageous genome complements having been assembled during hybridisation to be retained over generations, in perpetuity. This is achieved through sets of homologous chromosomes in fescue hybrid species pairing at meiosis in a preferential manner as intraspecific homologous chromosome associations. These segregate during gamete formation so that all constituent genome complements are maintained and transferred into subsequent generations.

Amongst polyploid fescues, the most studied is tall fescue, $F$. arundinacea $(6 x)$. A detailed cytological study involving genomic in situ hybridisation (GISH) (Humphreys et al. 1995) showed that it evolved following hybridisation of $F$. pratensis $(2 x)$, endemic to northern and western Europe, and $F$. arundinacea var. glaucescens $(4 x)$, a grass species indigenous to southern Europe with adaptations to Mediterranean climates. The hybridisation of the two fescue species, and subsequent intermediary events that enabled genome duplication, led over the millennia to the speciation of hexaploid F. arundinacea Schreb. (tall fescue). Genome interactions between the constituent genomes of tall fescue provided it with considerable adaptive plasticity and tolerance to contrasting temperature extremes and water availabilities.

Detailed genetic studies demonstrated that the strict homologous intraspecific chromosome pairing practised by tall fescue led to diploid-like meiosis and disomic inheritance (Lewis et al. 1980) ensuring the advantageous species' combinations were always maintained. Jauhar (1975) proposed that in addition to structural affinities that encouraged preferential homologous chromosome pairing in tall fescue and related polyploid fescue species, this property was supported further through the activity of a genetic chromosome pairing control regulator. Jauhar (1975) proposed the regulator in the fescues to be hemizygous ineffective, so that subsequent to hybridisation with another species it becomes nonfunctional, which would then permit homoeologous chromosome recombination to proceed unhindered and enable interspecific genetic transfers.

The broad-leaved fescues regularly employed in 
Festulolium research and breeding (Ghesquière et al. 2010a, b) belong to Festuca subg. Schedonorus and comprise two geographical lineages, the African clade (F. mairei, $F$. arundinacea subsp. atlantigena, and $F$. arundinacea var. letourneuxiana), and the European clade (F. pratensis, $F$. arundinacea, $F$. pratensis var. apennina and F. arundinacea var. glaucescens) (Torrecilla and Catalan 2002). An unknown diploid progenitor species is believed to be the source of the chromosome pairing regulator and to be common and central to speciation events within the European and most likely the African Schedonorus clade. It is speculated that this species contributed a common genome to $F$. pratensis var. apennina, F. arundinacea var. glaucescens and F. arundinacea (Kopecky et al. 2016).

All species from the European clade, with the exception of $F$. pratensis var. apennina, have been involved in the Festulolium cultivar development, but from the African clade, so far only $F$. maire $i$ has been so involved. Breeding successes using $F$. mairei were reported initially by Chen and Sleeper (1999), and later by Humphreys et al. (2014b, 2018) who developed cv. AberRoot, which recently gained entry onto the 2020 UK National List.

Humphreys (1989) was the first to describe the use of a pentaploid $L$. multiflorum $\times F$. arundinacea $(2 n=5 x=35)$ hybrid as part of a backcross-breeding programme aimed at transferring $F$. arundinacea traits into Lolium. Humphreys and Ghesquière (1993) later demonstrated the efficacy of the procedure using a polyallelic isozyme marker capable of discriminating isoalleles at orthologous chromosome sites on each of the five constituent genomes in the pentaploid hybrid. They demonstrated different frequencies in recombination rates between the Lolium and Festuca homoeologous chromosomes carrying the marker. Introgression of alleles from tall fescue into ryegrass favoured chromosome transfers from the $F$. pratensis genome more than from those of $F$. arundinacea var. glaucescens (a more distant relative). The research was the first to demonstrate conclusively that all three tall fescue genomes were accessible for gene transfers into ryegrass, and that a pentaploid hybrid between L. multiflorum and $F$. arundinacea was an effective starting point for introgression breeding programmes involving these species.

It has been long recognised that knowledge of the taxonomical and evolutionary relationships among species within the Lolium-Festuca complex would aide species selection and guide the strategy for interspecific plant breeding programmes. The complex phylogenetic relationships of Lolium and Festuca species and their grass relatives have been studied repeatedly by many researchers. Species' hybrids were studied, initially using morphological traits and also their cytological behaviour (e.g., Malik and Thomas 1966, Borrill et al. 1980). The cytology was later given significant support through the use of genomic in situ hybridisation (GISH) technologies (e.g. Thomas et al. 1994, Zwierzykowski et al. 1998, 2008, Canter et al. 1999, Kopecký et al. 2005). The application of GISH to mitotic and meiotic chromosome spreads of interspecific hybrids contributed new understanding of genome constitutions (e.g., Humphreys et al. 1995), and opportunities to physically locate the DNA of large chromosome translocations $(>1 \mathrm{~kb})$. By integrating cytogenetic and phenotypic studies, researchers were able to locate several quantitative trait loci (QTL) that governed expression of important traits, such as drought tolerance on chromosome 3 (Humphreys and Pašakinskienè 1996).

More detailed understanding of phylogenetic relations within the Lolium-Festuca complex was made possible by the applications of chloroplast (e.g., Cheng et al. 2016), nuclear DNA markers (e.g. Stammers et al. 1995), rDNA nucleotide sequence analysis (e.g., Torrecilla and Catalàn 2002), and markers such as sequence related amplified polymorphism (SRAP) (Cheng et al. 2015). More broadly, these studies provided understanding of relationships with other grass and cereal crop species within the Poaceae, and permitted comparative studies of genome organisation and function (e.g., Yamada et al. 2005, Armstead et al. 2007).

Species classification and the nomenclature used within this review have been employed consistently over the last century and appear regularly in publications by most European researchers, including those by the current authors, and are also used widely elsewhere (e.g. in Cheng et al. 2016). The term Festulolium conforms to specific EU directives and is applied to all ryegrass/fescue hybrid cultivars, irrespective of their species derivation, and is used in their commercial marketing. As a consequence, it would seem unlikely, that a change to the current nomenclature, will be forthcoming in Europe. However, it should be stated that the above species' nomenclature, classification and use are not consistently applied worldwide. In particular, in the USA, any reference to Lolium and Festuca species are usually replaced by alternative nomenclature and incorporated regularly on certain databases. It was suggested that the broad-leaved fescues in subgen. Schedonorus should better be included within Lolium (Darbyshire and Warwick 1992). The suggestion arose despite the obvious differences in the inflorescence morphology between ryegrasses and fescues, the fescues having open panicles and the ryegrasses with compact spikes. Other taxonomists have suggested a split of the subgen. Schedonorus into an independent genus, Schedonorus (e.g. Sorreng and Terrell 1997). In order to assist in their cross-reference, those fescue species used most frequently in Festulolium breeding (see Table 1 Suppl.) are listed below with some (but not all) of their alternative nomenclature. Meadow fescue (Festuca pratensis) is Lolium pratense (Huds.) Darbysh, or Schedonorus pratensis (Huds.) P. Beauv. Tall fescue (F. arundinacea) is Lolium arundinaceum (Huds.) Darbysh., or Schedonorus arundinaceus (Schreb.) Dumort.

A growing understanding of genome synteny in Poaceae crop species (e.g., Yamada et al. 2005, Armstead et al. 2006) allowed researchers to "fast-track" knowledge transfers of genome structure from extensively studied crop species, to those far less explored species, including species within the Lolium-Festuca complex. The strategy enabled the successful prediction of QTL location relevant to a range of complex traits, and enabled their respective genome sequences to be compared effectively. For example, Alm et al. (2011) described two major 
frost/tolerance/winter survival QTL on $F$. pratensis chromosome 5 that are likely to correspond to equivalent $F r$-Al and $F r-A 2$ loci found on chromosome 5A of wheat. They also described a large QTL for drought tolerance on $F$. pratensis chromosome 3 that would likely incorporate orthologous gene sequences reported in $F$. arundinacea and F. arundinacea var. glaucescens. These had, subsequent to their introgression onto chromosome 3 of L. multiflorum from the fescue species, been shown conclusively to confer to it an enhanced drought tolerance (Humphreys and Pašakinskienè 1996, Humphreys et al. 2005).

Identifying QTL locations by associations to gene markers aligned along specific chromosome linkage groups has been a helpful support to Lolium-Festuca spp. genome studies. QTL-maps were constructed for traits of importance both in Festuca pratensis (Alm et al. 2011), and in Lolium perenne (Turner et al. 2008). Unfortunately, there are frequently practical difficulties in translating knowledge of QTL location derived from experimental genetic mapping populations for use in alternative germplasm, including breeders' lines used in cultivar development.

Introgression-mapping is a technology that attempts to integrate genomic and phenotypic studies. From a plant breeding perspective, it has advantages over QTL analysis in that alien genome sequences are targeted specifically for selection across generations. This can be achieved whilst otherwise maintaining the host genome intact and limiting incidents of linkage drag that might otherwise deteriorate crop performance. Two exemplar studies demonstrate the efficacy of introgression-mapping and its direct applications into plant breeding and cultivar development. The first involved a simple gene trait, the recessive stay-green mutant Sid, and the second, a complex quantitative trait for drought tolerance. In the first example, introgressionmapping enabled the location and transfer of a stay-green mutant Sid onto a distal location of chromosome 5 in Lolium. In order to function, recessive gene Sid has to be transferred onto homologous Lolium spp chromosome sites. A L. perenne turf grass cv. AberNile, homozygous for the Sid gene, was commercialised and used widely as an amenity and sports grass in the 1980s. To this day, the stay-green gene remains the most extensively researched example of the use of introgression-mapping relevant to the Lolium-Festuca complex. It is an excellent example of the use of marker-assisted selection as a technique to aide trait selection within cultivar development (Thomas et al. 1997). The Sid gene, which has been isolated and sequenced, was later discovered to be orthologous to the gene for yellow/green cotyledon polymorphism reported by Gregor Mendel in 1886 (Armstead et al. 2007). Introgression-mapping for complex traits, and QTL selection, has been more challenging, but there have been notable successes. One involved plants derived from a backcross introgression-breeding population exposed to simulated prolonged drought conditions. In the best drought survivors, it was found, firstly by GISH, and subsequently using associated genetic markers that an identical Festuca-derived DNA sequence was recovered. Consistent amongst the best drought survivors were genotypes that carried a translocated $F$. arundinacea var. glaucescens DNA sequence at the same distal location of the L. multiflorum chromosome 3 (Humphreys et al. 2005). The fescue-derived sequence retained effective expression of drought tolerance over generations and in a broad array of alternative genetic backgrounds. The marker-assisted transfer of the fescue genes into a L. multiflorum breeding population led to the development of the IBERS-bred and UK National Listed Festulolium cultivar AberLink. The fescue-derived sequence was transferred subsequently from the L. multiflorum cultivar into a $L$. perenne breeding population where its drought tolerance was retained (Humphreys et al. 2012).

However, introgression-mapping for major QTL in Lolium-Festuca populations has not always been as successful. Harper et al. (2018) found, when investigating genotype-phenotype association within a genomecharacterised L. perenne/F. pratensis introgressionmapping population, that phenotype expression attributed to a fescue chromosome was on occasions subsequently lost in progeny, despite the retention of the relevant fescuebased translocations.

Introgression-mapping frequently supports plant physiology investigations. Through its targeted approach, it provides an opportunity for complex traits to be effectively "dissected" so that their underlying mechanisms are revealed. A good example was a drought tolerant experimental Festulolium cultivar Bx509 (Humphreys et al. 2018). This cultivar contained a $F$. arundinaceaderived DNA sequence introgressed onto the long arm of chromosome 3 of L. perenne cv. AberStar, at a proximal location. Using high-throughput and detailed phenotyping, it was demonstrated that Bx509 had a significantly larger and deeper root system compared to cv. AberStar, which in all likelihood aided its drought tolerance. The introgression-mapping technologies also helped to identify genes involved in the photosystem II cold-acclimation in F. pratensis (Humphreys et al. 2006a), and in Festulolium cultivars (Rapacz et al. 2004).

Whilst the potential for Festulolium use has been recognised widely, until recently it is only in Central and Eastern Europe that there has been a consistent strategy for Festulolium breeding, and there is a continuous pipeline of developing new cultivars. However, recent political, economic and environmental drivers have refocused thoughts and priorities elsewhere, and, especially the UK, aimed at seeking new and more environment-friendly and sustainable solutions in agricultural production. In this new scenario, and taking into account essential requirements to mitigate climate change, there are ever-increasing opportunities for Festulolium cultivar use (Humphreys et al. 2014b), which should broaden their global appeal.

\section{Breeding of Festulolium cultivars}

Throughout the history of Festulolium breeding, the primary objective has been to combine the high yield and quality of ryegrasses with abiotic stress tolerance of fescues. This was to enhance grassland persistence, and to 
maintain sustainable forage production (Ghesquière et al. 2010a). As previously described, Festulolium cultivars can be developed via the amphiploid approach, with the intention to combine entire Lolium and Festua genome complements, or via the introgression-breeding approach, where specific genes from a donor species are incorporated into the otherwise undisturbed genome of the host species (Ghesquière et al. 2010a).

The first amphiploid Festulolium cultivar Elmet $[=\times$ Festulolium braunii $(\mathrm{K}$. Richter) A. Camus $]$, is amphidiploid $(2 \mathrm{n}=4 x=28)$ and was developed in the early 1970s at the Welsh Plant Breeding Station, Aberystwyth, UK (Lewis et al. 1973). The cultivar was obtained by hybridising colchicine-induced autotetraploid $(2 n=4 x=28)$ forms of diploid L. multiflorum $(2 n=2 x$ $=14)$ and $F$. pratensis $(2 n=2 x=14)$. The same research group, using the same breeding approach, produced the allotetraploid cv. Prior from hybrids of $L$. perenne $(4 x)$ $\times F$. pratensis $(4 x)[=\times$ Festulolium loliaceum (Huds.) P. Fourn.]. Cv. Prior gained entry onto the Swedish National Recommended List and was also employed in breeding programmes elsewhere, such as in the USA (Casler et al. 2001), and in Norway (Østrem et al. 2013). The cultivar was later assessed in the UK for additional ecosystem service properties (Macleod et al. 2013). However, neither cv. Elmet nor cv. Prior were ever registered onto the UK National Recommended Lists, a prerequisite to their commercial use. In the 1980-2000s, multiple successes in breeding of Festulolium amphiploid cultivars followed, especially in Central and Eastern Europe, and several cultivars were registered as $\times$ Festulolium braunii. In Czechoslovakia (now, the Czech Republic), at the Hladké Životice Breeding Station (recently DLF Seeds, s.r.o.), Antonin Fojtik and his co-workers developed several Festulolium cultivars which were commercialized in many countries, and still remain on the OECD list.

The restrictive definition of Festulolium prior to 2004, which limited marketing to single species combination (Festulolium braunii), was a significant obstacle to Festulolium breeding. F. arundinacea (tall fescue) has over many years been considered as incorporating many traits deemed desirable for inclusion in a persistent grass cultivar (e.g. drought tolerance, large root biomass). Effective breeding programmes to introduce $F$. arundinacea traits into Lolium were initiated (e.g. Humphreys and Ghesquière, 1993). However, the constraints prior to 2004 prevented their inclusion as Festulolium. As a consequence, promising cultivars derived from L. multiflorum/F. arundinacea hybrids, were included on tall fescue National Lists. In the USA, at the Kentucky Agricultural Experiment Station, Lexington, Buckner et al. $(1977,1983)$ developed two hexaploid tall fescue cultivars, Kenhy (1977) and Johnstone (1983) through an introgression-breeding approach. These derived from fertile colchicine-induced amphiploids $(2 n=$ $8 x=56$ ), produced from initially sterile tetraploid hybrids of $L$. multiflorum $(2 x) \times F$. arundinacea $(6 x)$.

In the Czech Republic, at the Breeding Station Hladké Životice, Fojtik (1994) developed an extensive breeding programme in which partly female fertile $F_{1}$ hybrids of
L. multiflorum $(2 x) \times$ F. arundinacea $(6 x)$ were backcrossed either onto hexaploid $F$. arundinacea or tetraploid L. multiflorum. In the former case, fourteen hexaploid tall fescue introgression cultivars including Felina (1989), Hykor (1991) and Korina (1997) were produced, and in the latter, five tetraploid Italian ryegrass introgression cultivars, such as Bečva (1989) and Lofa (1997).

Seventy-eight Festulolium cultivars have been released globally (listed in Table 1 Suppl.). These comprise 33 cultivars derived through the amphiploid approach, and 45 cultivars derived from the introgression approach. Of these, 53 are registered on the 2020 OECD List, a prerequisite for seed marketing in most countries.

Ghesquière et al. (2010a) reviewed progress in Festulolium cultivar development between the 1970s and 2010. They listed a total of 42 cultivars (incorporated into Table 1 Suppl.), of which 23 were amphiploid and 19 were introgressive forms. During the last 10 years, Festulolium breeding has advanced considerably. Most striking are the increased numbers of cultivars derived through the introgression-breeding approach. Compared to earlier times, the number of such cultivars currently available has more than doubled, from 19 in 2010 to 46 in 2020. Some of the cultivars listed in Table 1 Suppl. no longer remain on the $O E C D$ List (e.g., Elmet, Rakopan, Prior, Lueur, Lusilium and Luxane), and new cultivars (e.g., Hopej, Honor, Hypnos, Lukida, and Naos) have yet to become registered on the $O E C D$ List.

Cultivars derived through an amphiploid-breeding approach (see Table 1 Suppl.): Thirty-three Festulolium cultivars, all tetraploid $(2 n=4 x=28)$, have been developed using the amphiploid-breeding approach. Twenty-three cultivars derive from reciprocal L. multiflorum $(4 x) q \times$ $F$. pratensis $(4 x)$ and $F$. pratensis $(4 x)$ ㅇ $L$. multiflorum (4x) hybrid combinations. Of these, seven were developed in the Czech Republic (Fojtik 1994, V. Cernoch, personal communication), four in Poland (Zwierzykowski et al. 1994, 1998, Jokś et al. 1995), four in Germany (e.g., Netzband 1991), three in Lithuania (Nekrošas et al. 1995, Nekrošas and Kemešyte 2007), two in the UK (e.g., Lewis et al. 1973), one in Japan (Kubota et al. 2015), and one each in Argentina and Italy. Among the five amphiploid cultivars derived from hybrids of $L$. perenne $(4 x) \times$ F. pratensis $(4 x)$, two were developed in Norway (Østrem et al. 2013), one in the UK (Lewis et al. 1973), and one in Japan (Kubota et al. 2015).

In addition to $F$. pratensis, the other progenitor species involved in the evolution of hexaploid $F$. arundinacea is the Mediterranean fescue, $F$. arundinacea var. glaucescens (4x) (Humphreys et al. 1995). Although, not used as regularly as $F$. pratensis or $F$. arundinacea in plant breeding, $F$. arundinacea var. glaucescens is now receiving increased interest and involvement. From tetraploid hybrids of $L$. multiflorum $(4 x) \times F$. arundinacea var. glaucescens $(4 x)$, three cultivars were developed in France (Ghesquière et al. 1996, 2010a, b).

Although it is yet to gain entry onto National Lists, an amphiploid cultivar $(\mathrm{B} \times 514)$ of the hybrid between $L$. perenne and $F$. arundinacea var. glaucescens $(4 \mathrm{x})$ 
with good overall agronomic performance has also demonstrated valuable ecosystem services (Humphreys et al. 2014). The cultivar has demonstrated its potential to support efficient ruminant nutrition and for combating soil compaction (Humphreys et al. 2014, Kamau et al. 2020, Muhandiram et al. 2020).

Festulolium cv. AberAtlas has been included onto the 2020 UK National List and globally is the first L. perenne $\times$ F. mairei amphiploid cultivar (Humphreys et al. 2014, 2018, Kamau et al. 2020).

Casler et al. (2001), in the USA, developed cv. Spring Green by inter-pollinating four existing Festulolium cultivars: Elmet, Tandem and Kemal (all L. multiflorum $\times$ F. pratensis), and cv. Prior (L. perenne $\times$ F. pratensis $)$.

Pedersen et al. (1990) registered germplasm KY-2N56 $(2 n=8 x=56)$, which originated from two hybrids: L. multiflorum $\times F$. arundinacea and F. arundinacea F. gigantea.

Cultivars derived through an introgression-breeding approach (see Table 1 Suppl.): Forty-five Festulolium cultivars have been developed following the introgressionbreeding approach. These involved backcrossing LoliumFestuca hybrids into either L. multiflorum, or L. perenne (for introducing fescue traits into ryegrass), or into $F$. arundinacea (for introducing ryegrass traits into tall fescue). For several introgression-bred cultivars, e.g. Evergreen, Kemal and Tandem (L. multiflorum $\times$ F. pratensis) and Barfest, Duo, Barier, Matrix, Revolution and Ultra (L. perenne $\times$ F . pratensis), knowledge over their fescue content is somewhat limited. The cultivars were classified as introgression lines based primarily on their phenotypes and Lolium-like appearance (Ghesquière et al. 2010a).

Twenty-four introgression-bred Festulolium cultivars derive from L. multiflorum F. arundinacea hybrids. Their development centred primarily at the Breeding Station Hladké Životice. As a starting point, tetraploid hybrids between L. muliflorum $(2 x)$ and $F$. arundinacea $(6 x)$ were, backcrossed onto one of the parent species (e.g., Fojtik 1994, Kopecký et al. 2005). Amongst 21 Czech Festulolium cultivars, 14 (all hexaploid, $2 n=6 x=42$ ) derived via introgression of $L$. multiflorum traits into $F$. arundinacea, and seven cultivars (all tetraploid, $2 n=$ $4 x=28)$ via introgression of $F$. arundinacea traits into L. multiflorum (V. Cernoch, personal communication).

Eight cultivars developed via an introgression breeding were obtained from backcrosses of L. multiflorum $(4 x) \times$ $F$. pratensis ( $4 x$ ) hybrids onto L. multiflorum ( $4 x)$. Three of those were produced in the USA (Casler et al. 2001), two in Switzerland (Ch. Grieder, personal communication), and the remaining in the UK (M. W. Humphreys, personal communication), Japan (Kubota et al. 2015) and Uruguay.

Seven Festulolium cultivars were developed by introgression of $F$. pratensis genes into $L$. perenne from initial $L$. perenne $\times F$. pratensis hybrids. Amongst these, four cultivars, all diploid, were developed in New Zealand (A. Stewart, personal communication). Three cultivars, all tetraploid, were obtained from backcrosses of $L$. $\times$ boucheanum $(=$ L. perenne $\times$ L. multiflorum) hybrids into
F. pratensis, two in Latvia (Bērziñš et al. 2018) and one in Belgium (J. Baert, personal communication).

There are two known examples of use of a targeted approach aimed at specific genetic transfers, in both cases from a donor fescue species into ryegrass that have led to cultivar registration. An integrated physical and genetic mapping approach involved using diploid drought-tolerant L. multiflorum genotypes incorporating $F$. arundinacea var. glaucescens genes as the starting point (Humphreys et al. 2005). These were the source of germplasm that led to the development of the drought-tolerant cv. AberLink (Humphreys et al. 2014b). Unique in Table 1 Suppl., as it is an amenity and not a forage grass, cv. AberNile was the first confirmed Festulolium introgression-line, and is a diploid $L$. perenne turf grass, homozygous for the recessive $F$. pratensis-derived allele $S i d$ for the stay-green trait (Thomas et al. 1997).

\section{Genomic constitution of Festulolium cultivars}

Over the years, cultivar development of synthetic Festulolium amphiploids has been seriously compromised by an inability to restrict pairing to true homologous chromosome partners. Incidents of homoeologous chromosome pairing that likely lead to aneuploidy, and over generations, compromise cultivars' genetic stability and fertility are regularly witnessed (Thomas and Humphreys 1991).

Cytogenetic studies using genomic in situ hybridization (GISH) have confirmed the significant extent of homoeologous pairing and interspecific genome recombination that occurs within Festulolium progenies (e.g., Zwierzykowski et al. 1998, 2006, 2011, Canter et al. 1999, Pašakinskienè and Jones 2003, Kopecký et al. 2005, 2006, 2017, Kubota et al. 2015). Zwierzykowski et al. (1998) were first to describe extensive homoeologous recombination in four $\mathrm{F}_{8}$ populations derived from F. pratensis $\times$ L. multiflorum hybrids $(2 n=4 x=28)$. These populations were registered in Poland as cultivars Agula, Felopa, Sulino, and Rakopan. Genome constitutions of these cultivars deviated greatly from the expected $50 \%$ Lolium: $50 \%$ Festuca. The percentage of the L. multiflorum chromatin ranged from 49.2 to $66.7 \%$. This would infer increasing genomic imbalance and the favoured transmission of Lolium as compared to Festuca chromatin. These conclusions were confirmed in other independent studies. Extensive incidents of genome imbalance and homoeologous recombination were observed in the $\mathrm{F}_{8}$ genotypes derived from the amphiploid L. perenne $(4 x) \times F$. pratensis $(4 x) \mathrm{cv}$. Prior (Canter et al. 1999). Similar findings were made in the Lithuanian cv. Punia (F. pratensis (4x) L. multiflorum (4x) (Pašakinskiene and Jones 2003).

Zwierzykowski et al. (2006, 2011) reported extensive interspecific chromosome recombination between the parental genomes in successive $\mathrm{F}_{2}-\mathrm{F}_{8}$ generations of breeding populations developed from $F$. pratensis $(4 x)$ O $\times$ L. perenne $(4 x)$ hybrids. They also reported multiple incidents of substitution of whole Festuca chromosomes by 
those of Lolium. The total number of Lolium chromosomes present increased from the mean of 14.4 in the $\mathrm{F}_{2}$ to 17.6 in the $\mathrm{F}_{8}$, while the corresponding Festuca chromosome number decreased from 13.6 to 10.5 .

Kopecký et al. (2006) analysed the genomic constitution of 26 Festulolium cultivars generated via both amphiploid and introgression-breeding approaches. They reported large variations in the proportions of parental genomes and in the extent of generic recombination in eleven amphiploid cultivars derived from reciprocal hybrids of $L$. multiflorum $(4 x) \times F$. pratensis $(4 x)$, and also in a $L$. perenne $(4 x) F$. pratensis $(4 x)$ cultivar, supporting earlier observations by Zwierzykowski et al. (1998) and Canter et al. (1999). In Festulolium cultivars developed by backcrossing $L$. multiflorum $(2 x) \times F$. arundinacea $(6 x)$ hybrids onto $F$. arundinacea, GISH analysis indicated a prevalence of the Festuca genome, and a high number of recombinant Lolium-Festuca chromosomes. In cultivars developed from $L$. multiflorum $(2 x) \times F$. arundinacea $(6 x)$ hybrids backcrossed onto L. multiflorum (4x), Kopecký et al. (2006) observed only Lolium chromosomes, and sporadically one or more recombined chromosomes. In three other cultivars, they were unable to detect the presence of any Festuca derived chromatin.

A multi-location three-year field trial was constructed in eight European countries by the members of a consortium within the EUCARPIA Fodder Crops and Amenity Grasses Section, Festulolium Working Group (Kopecký et al. 2018). Each site included the same 15 elite Festulolium cultivars and representative cultivars of their parental species, used as controls. In addition to comparative studies in their field performance, a detailed investigation of their genome constitution using both GISH and Diversity Arrays Technology (DArT), was undertaken. The Festulolium cultivars included forms from both amphiploid and introgression-breeding. Species combinations included L. multiflorm $\times$ $F$. arundinacea var. glaucescens, L. multiflorum x $F$. arundinacea, L. multiflorum $\mathrm{x} F$. pratensis, and L. perenne $\mathrm{x} F$. pratensis. Over the wide range of cultivars of distinct and different origins, the genome study found widespread predominance in the retention of Lolium, compared to Festuca-derived chromatin.

Differences in genome compositions within Festulolium amphiploid cultivars were often larger than those between cultivars, thereby illustrating the difficulties for breeders in achieving the necessary uniformity required for cultivar registration. The extent of the variation in genomic constitution, both within and between cultivars, is likely to be affected by the number of generations of seed multiplication undertaken subsequent to generating the initial $F_{1}$ hybrids. Unfortunately, there is only limited data available in this regard. All Czech and Polish allotetraploid Festulolium cultivars investigated are derived from advanced breeding materials, i.e., $\mathrm{F}_{8}-\mathrm{F}_{9}$ generations (Kopecký et al. 2006).

The genome instability in the Festulolium allotetraploid hybrids listed above all refer to Lolium spp. in hybridisation to $F$. pratensis. It is possible that in less investigated and more distant Lolium/Festuca spp. hybrid combinations that genome integrity may be greater.

Kopecký et al. (2018) reported that L. multiflorum $\times$ F. arundinacea var. glaucescens cv. Lueur (4x) has nearly equivalent amounts of chromatin from its parental species. $\mathrm{Cv}$. Lueur, and more recently, L. perenne $\times F$. mairei cv. AberRoot (4x) (M.W. Humphreys, unpublished results) are the only known amphiploid Festulolium cultivars to retain, to a large extent, a balanced genome constitution (i.e. at least over ca $\mathrm{F}_{8}-\mathrm{F}_{9}$ generations). In addition to factors encouraging preferential chromosome pairing, incorporation of a functional chromosome-pairing regulator, proposed by Jauhar (1975) as an important stage in the evolution of fescue polyploids, would further improve hybrid genome integrity across generations, and support cultivar development.

\section{Festulolium for ecosystem services}

Grasslands are now increasingly recognised for their wide contributions to society and for their delivery of "public good" service, in addition to their better acknowledged roles for use in livestock agriculture (Abberton et al. 2008, Humphreys et al. 2014b). Amongst their numerous and diverse properties, grasslands provide carbon and water catchment provisions. They help regulate the acquisition and storage of rainfall in soils, and its subsequent release into river systems. They have an important role in preventing soil erosion and in assisting the regulation and retention of essential plant nutrients. Thereby, grasslands help to prevent river pollution and to maintain water quality. Grasslands are also important for in situ conservation of genetic resources, and are major providers of habitat for essential insect pollinators required for seed and fruit production by many crop species.

Festulolium cultivars have been developed to help maintain sustainable forage crop production, and through their resilience, to provide farmers some security against onsets of climatic stress. Although Festulolium cultivars have in the main involved only two fescue species ( $F$. pratensis and $F$. arundinacea), they increasingly now derive from alternative species' combinations. Even when having the same species combination, cultivars may vary in the proportions of their constituent Lolium and Festuca genomes (Kopecký et al. 2006, 2018, Ghesquière et al. 2010a,b). Moreover, the parent species used to generate Festulolium cultivars are highly heterogeneous. Cultivars developed in different breeding programmes, even if the species' combinations are the same, will be genetically dissimilar. As a consequence, the extent of the various ecosystem services provided by Festulolium cultivars, will differ. If they are to achieve their intended function, it is essential that they are chosen and used only in the locations and for the purposes for which they were designed.

An important feature of perennial grasslands is the enormous biomass they produce below ground (Newman et al. 1989), a feature considered highly relevant to the provisions of ecosystem services (Bardgett et al. 2014). A survey of old grassland in the UK carried out by Dickinson and Polwart (1982) measured root biomass of around 
$5 \mathrm{tha}^{-1}\left(0.5 \mathrm{~kg} \mathrm{~m}^{-2}\right)$ in the top $15 \mathrm{~cm}$ of soil. Fescue species characteristically have larger and deeper root systems than ryegrasses (Cougnan et al. 2017). Festulolium cultivars frequently demonstrate combined rooting characters found in their parent species. Like ryegrasses, Festulolium cultivars frequently have significantly higher root branching, in particular in soils near to the surface, than are found in fescues. However, compared to ryegrass, Festulolium generally have superior root biomass and root depth (Cougnan et al. 2017, Humphreys et al. 2018). In a small but detailed study, Durand et al. (2007) using $\mathrm{O}^{18}$ demonstrated that Festulolium hybrids extracted water at soils depths inaccessible to Lolium cultivars, which would clearly assist them in providing greater drought tolerance.

Many ecological and environmental benefits emanate from the interactions between the roots of Festulolium and the soils in which they grow, for example, for flood mitigation (Macleod et al. 2013).

Until recently, grass breeding targets had focused only on the above-ground traits, mainly due to the difficulties in root phenotyping and selection. As a consequence, plant breeders have largely neglected improvements to root design and behaviour. New high-throughput root phenotyping technology is now becoming incorporated in plant selection, and into new breeding strategies. The incorporation of detailed root imaging undertaken at the National Plant Phenomics Centre (NPPC) in Aberystwyth is an example where detailed characteristics of root ontogeny and turn-over over entire growing seasons are now measured regularly, and with increasing efficiency, both in grasses and clovers (Marshall et al. (2016).

Festulolium cultivars have demonstrated their hidden values through their beneficial root-soil interactions. The first registered Festulolium loliaceum cultivar, cv Prior, produced in the 1970s has demonstrated a very timely ecosystem service, at a time of increased rainfall intensity. Through its deep rooting properties and significant root senescence at depth at the end of the growing season, cv Prior has demonstrated an ability to enhance soil structure and thereby increase soil porosity aiding soil water retention and mitigating surface flooding. This property was demonstrated within two consecutive multidiscipline BBSRC-funded programmes, initially using replicated field plots within the "SuperGrass" project (Macleod et al. 2013) project. Subsequently, the cultivar was tested both with or without white clover at the field scale, and including the use of livestock within the "SureRoot" project (BB/L009889/1; www.sureroot.uk).

Using hydrologically isolated field plots in the BBSRC "SuperGrass" project at Rothamsted Research North Wyke Research Station, it was demonstrated how cv. Prior, when compared to cultivars of its parental species, consistently reduced rates of surface run-off (a $70 \%$ reduction compared to a registered perennial ryegrass cultivar, and a $43 \%$ reduction compared to a meadow fescue cultivar). The results suggested a role for Festulolium for flood mitigation. The hypothesis was subsequently tested within the BBSRC "SureRoot" project. Using hydrologically isolated fields at the North Wyke Farm Platform (NWFP), an independent modelling study (Li et al. 2017) demonstrated the benefits to soil hydrology from cv. Prior in delaying surface run-off, especially following extreme rainfall. The "SureRoot" project demonstrated that the benefits of Festulolium were even greater when grown in mixtures with white clover. Through root senescence, $\mathrm{Li}$ et al. (2017) also demonstrated that the Festulolium cultivar could contribute to carbon sequestration in soils. In their modelling study, Festulolium cv. Prior was predicted to have potential to fix more, and to lose less $C$ through soil respiration than a current registered $L$. perenne cultivar. In their calculations, Li et al. (2017) suggested that soil $\mathrm{C}$ storage with reseeded $\mathrm{cv}$. Prior gradually increases by $0.525 \mathrm{t}(\mathrm{C}) \mathrm{ha}^{-1}\left(0.0525 \mathrm{~kg}(\mathrm{C}) \mathrm{m}^{-2}\right)$ in two years following reseeding.

In order to enhance efficiencies in $\mathrm{C}$ soil deposition in grassland soils and for future benefit to the environment, $\mathrm{C}$ sequestration from grass root turn-over should focus primarily on those more biologically inert deep soil profiles (Kell 2011). Recent root research, such as that of Macleod et al. (2013) and Li et al. (2017), would suggest a role in this regard for deep rooting Festulolium cultivars.

Other research undertaken on working farms within the "SureRoot" project involved trials comparing field performance of the Festulolium cv. AberNiche, an Italianryegrass-like introgression cultivar and registered hybrid ryegrass cultivar as a control. Root biomass was found to be higher for cv. AberNiche when grown on farms with sandy soils. Similar to the outcomes reported in Macleod et al. (2013), the autumn water infiltration rates were higher across all farms and livestock systems in the Festulolium areas $\left[30.7 \pm 5.87(\mathrm{SEM}) \mathrm{cm} \mathrm{h}^{-1}\right]$ compared to the ryegrass areas $\left[16.6 \pm 2.1(\mathrm{SEM}) \mathrm{cm} \mathrm{h}^{-1}\right]$ (Powell et al. 2018).

Another outcome of the "SureRoot" project, (C. Marley, personal communication), was the finding that number of earthworms found was far greater in soils under Festulolium cv. AberNiche (L. multiflorum $\times$ F. pratensis) and cv. AberRoot (L. perenne $\times F$. mairei) than in adjoining soils under ryegrass at the same farm location and under the same field managements.

The technologies now becoming available to researchers and breeders provide the means to monitor root growth throughout the growing season and offer new insight into grass crop development. Precision rootscan photography provided the first detailed comparisons in root ontogeny of ryegrass, Festulolium amphiploid hybrids, and Festulolium introgression lines throughout a growing season (Humphreys et al. 2018). An experimental amphiploid population of $L$. perenne $\times F$. arundinacea $v$ ar. glaucescens (Bx514), and of Festulolium cv. AberAtlas (L. perenne $\times F$. mairei), both with forage growth equivalent to control L. perenne cultivar (Humphreys et al. 2014a), had significantly greater root biomass and root depth (Humphreys et al. 2018). The greater root growth of the Festulolium hybrids showed no negative impact to compromise their forage production.

Root phenomics demonstrated that Bx509, a Festulolium population with a sequence of $F$. arundinacea-derived genes for drought tolerance in an otherwise complete genome of $L$. perenne $\mathrm{cv}$. AberStar, had significantly greater root biomass than cv. AberStar, a likely explanation 
for its superior drought tolerance (Humphreys et al. 2018). In a $L$. perenne linkage-mapping population, Turner et al. (2008) demonstrated that QTLs associated with large root systems were also associated with drought tolerance and foliar growth. The findings, later supported by Humphreys et al. (2018), were that grasses with high forage production frequently have large root systems providing them some resilience to soil water deficits.

As far as the authors are aware, breeding to mitigate impacts from soil compaction derived either from livestock or machinery compressions and often exacerbated by prolonged droughts or floods, have until recently been absent. Soil compaction affects both soil and forage productivity. A recent investigation compared the impacts from machinery-derived soil compaction, both on field performance, and on underlying soil characters using plots with grass species of different root biomass, including three Festulolium cultivars (Muhandiram et al. 2020). Overall, findings showed that alternative grass root structures conveyed differing resilience to compaction. Amongst the L. perenne, F. arundinacea and Festulolium cultivars tested, it was a L. multiflorum $\times F$. arundinacea var. glaucescens population $(\mathrm{B} \times 514)$, that provided resilience to soil compaction without compromising forage productivity (Muhandiram et al. 2020).

However, the benefits of Festulolium are not restricted solely to the below ground properties, and, compared to ryegrass, include improved efficiencies in ruminant nutrition through better protein provision for livestock. An increase in the protein-use-efficiency by ruminants should result in reduced nitrogenous wastes and greenhouse gas emissions that are frequently associated with livestock agriculture (Humphreys et al. 2014, Kamau et al. 2020). There is growing evidence that Festulolium cultivars may provide some additional ecosystem services via their positive impacts on ruminant nutrition. Livestock agriculture is increasingly criticised for its negative impacts on the environment, and in particular, for the associated releases of nitrous wastes and greenhouse gasses: ammonia, nitrous oxide and methane, a consequence of inefficient plant protein use by ruminants. This is largely due to plant-mediated proteolysis of fodder when ingested by ruminants and is catalysed by both microbial, but initially, endogenous plant proteases (Kamau et al. 2020).

Alternative grass breeding approaches have been undertaken over recent years to improve feed efficiencies in ruminants. The best known are the development of high sugar ryegrasses, designed to increase rumen microbes and through their activities, enhance the nitrogen uptake from fodder (Wilkins and Humphreys 2003). However, an alternative strategy that involves Festulolium instead of ryegrass, provides a possible complementary approach. This focuses on lowering of the initial protein intake by ruminants, and subsequently, to support ingested protein retention, in order to allow greater time for uptake by the animal and conversion into meat and dairy products. Through a series of in vitro studies, it has been demonstrated that certain fescue species, like $F$. arundinacea var. glaucescens have, compared to ryegrass, up to four times greater protein retention when subjected to rumen-like conditions (Shaw 2006). The fescue trait for decreased rates of endogenous protein degradation remains expressed in certain amphiploid Festulolium cultivars. Moreover, this trait is accompanied by overall forage yields and quality equivalent to ryegrass (Humphreys et al. 2014a, O’Donovan 2015).

Under simulated rumen-conditions, both the amphiploid Festulolium population Bx514 (L. multiflorum $\times$ F. arundinacea var. glaucescens, and Festulolium cv. AberRoot (L. perenne $\times F$. mairei) demonstrated significantly lower plant-mediated proteolysis than their ryegrass control (Kamau et al. 2020). Although no differences in microbial protein synthesis were observed during early fermentation ( $0-6 \mathrm{~h}$ after feeding), an increase in microbial $\mathrm{N}$ flow in cv. AberRoot $(+30 \%)$ and in $\mathrm{Bx} 514$ $(+41 \%)$ was observed during late fermentation $(6-24 \mathrm{~h}$ after feeding). There were higher overall microbial $\mathrm{N}$ flows $(+13.5 \%$ for $\mathrm{cv}$. AberRoot, and $+20.2 \%$ for Bx 514$)$ when compared to the ryegrass control (Kamau et al. 2020). These observations indicate the potential for Festulolium cultivars that express the slow plant-mediated proteolysis trait to improve on efficiencies of forage protein capture and to decrease the releases of $\mathrm{N}$ pollutants onto the land.

The research described above focused only on freshly harvested Festulolium plant material and its impacts on ruminant nutrition. Very recently, this has been extended further on whether similar benefits might be evident in 90 day-old silage (Muhandiram et al. 2020). The initial findings are promising and indicated that crude protein content obtained from silage generated from cut foliage of the Festulolium population Bx514 (L. perenne $\times$ Festuca arundinacea var. glaucescens) was significantly higher than corresponding silage obtained from a high yielding current high sugar ryegrass cultivar.

\section{Conclusions}

Grasslands are multifunctional; using a holistic breeding approach, new cultivars would be evaluated not only as fodder for livestock, but also for the provision and range of important ecosystem benefits. It is increasingly necessary to develop high yielding cultivars with resilience against the various climate-change scenarios they may encounter. Festulolium cultivars may provide the necessary phenotype plasticity that brings such multiple benefits and bespoke options that can be tailored to the specific requirements of farmers and society. By incorporating new highthroughput phenomic and genomic technologies, complex advantageous traits may be assembled together in single cultivars.

The geographic range of Festulolium could expand in future years due to their resilience to abiotic stresses and to their ecosystem services. They offer potential sustainable high yielding and high-quality forage grasses that can bring economic and social benefits to farmers in developing countries. For example, a recent study undertaken by farmers in Kenya compared the field performance of IBERS-bred grasses; two UK National Listed perennial ryegrass cultivars and five Festulolium cultivars (Mwendia 
et al. 2019). The grasses were compared over one growing season on clay loam soils at Ol-joro-Orok in the central highlands of Kenya at about 2600 - 2800 m a.s.l. An evaluation by 61 local dairy farmers rated the grasses on criteria they nominated as being important, including dry matter yield, growth rate, height, frost tolerance, disease tolerance and leafiness. The Festulolium cultivars collectively outperformed the ryegrass cultivars. Mwendia et al. (2019) concluded that the grasses had definite potential for future commercial use in grassland livestock systems in Kenya. The results in Kenya, and elsewhere show there is an increasing range of new opportunities for use of Festulolium cultivars.

\section{References}

Abberton, M.T., Marshall, A.H., Humphreys, M.W., MacDuff, J.H., Collins, R.P., Marley, C.L.: Genetic improvement of forage species to reduce the environmental impact of temperate livestock grazing systems. - Adv. Agron. 98: 311$355,2008$.

Alm, V., Busso, C.S., Ergon, Å., Rudi, H., Larsen, A., Humphreys, M.W., Rognli, O.A.: QTL analyses and comparative genetic mapping of frost tolerance, winter survival and drought tolerance in meadow fescue (Festuca pratensis Huds.). Theor. appl. Genet. 123: 369-382, 2011.

Armstead, I., Donnison, I., Aubry, S., Harper, J., Hörtensteiner, S., James, C., Mani, J., Moffet, M., Ougham, H., Roberts, L., Thomas, A., Weeden, N., Thomas, H., King, I.: From crop to model to crop: identifying the genetic basis of the staygreen mutant in the Lolium/Festuca forage and amenity grasses. New Phytol. 172: 592-597, 2006.

Armstead, I., Donnison, I., Aubry, S., Harper, J., Hörtensteiner, S., James, C., Mani, J., Moffet, M., Ougham, H., Roberts, L., Thomas, A., Weeden, N., Thomas, H., King, I.: Cross-species identification of Mendel's locus. - Science 315: 73, 2007.

Bardgett, R.D., Mommer, L., De Vries, F.T.: Going underground: root traits as drivers of ecosystem processes. - Trends Ecol. Evol. 29: 692-699, 2014.

Bērziņš, P., Rungúis, D., Rancāne, S., Gailīte, A., Beḷeviča, V., Stesele, V., Vēzis, I., Jansons, S.: Yield and genetic composition of Latvian $\times$ Festulolium cultivars and breeding material. - In: Brazauskas, G., Statkevičiutè, G., Jonavičienė, K. (ed.): Breeding Grasses and Protein Crops in the Era of Genomics. Pp. 62-66. Springer International Publishing, Dordrecht 2018.

Boller, B., Kopecký, D.: Extraordinary heterosis found in a forage grass hybrid, Festuca apennina $\times F$. pratensis. - Research Square DOI: 10.21203/rs.2.22666/v1. 2020.

Borrill, M., Kirby, M., Morgan, W.G.: Studies in Festuca 12. Morphology, distribution and cytogenetics of $F$. donax, $F$. scariosa and their hybrids, and the evolutionary significance of their fertile amphiploid derivative. - New Phytol. 86: 423439, 1980.

Buckner, R.C., Burrus II, P.B., Bush, L.P.: Registration of 'Kenhy' tall fescue. - Crop Sci. 17: 672-673, 1977.

Buckner, R.C., Boling, J.A., Burrus, II, P.B., Bush, L.P., Hemken, R.A.: Registration of 'Johnstone' tall fescue. - Crop Sci. 23: 399-400, 1983

Canter, P.H., Pašakinskienè, I., Jones, R.N., Humphreys, M.W.: Chromosome substitutions and recombination in the amphiploid Lolium perenne $\times$ Festuca pratensis cv. Prior $(2 n$ $=4 x=28)$. - Theor. appl. Genet. 98: 809-814, 1999.
Casler, M.D., Pitts, P.G., Rose-Fricker, C.A., Bilkey, P.C., Wipff, J.K.: Registration of 'Spring Green' Festulolium. - Crop Sci. 41: 1365-1366, 2001.

Chen, C., Sleper, D.A.: FISH and RFLP marker-assistedintrogression of Festuca mairei chromosomes into Lolium perenne. - Crop Sci. 39: 1676-1679, 1999.

Cheng, Y., Ma, X., Zhou, K., Humphreys, M.W., Zhang, X.Q.: Phylogenetic analysis of Festuca-Lolium complex using SRAP markers. - Genet. Resour. Crop Evol. 63: 7-18, 2015.

Cheng, Y., Zhou, K., Humphreys, M.W., Harper, J.A., Ma, X., Zhang, X., Yan, H., Huang, L.: Phylogenetic relationships in the Festuca-Lolium complex (Loliinae: Poaceae): new insights from chloroplast sequences. - Front. Ecol. Evol. 4: 89, 2016.

Clayton, W.S., Renvoize, S.A.: Genera Graminum: grasses of the world. - Kew Bull. Add. Ser. 13: 1-389, 1986.

Cougnan, M., De Swaef, T., Lootens, P., Baert, J., De Frenne, P., Shahidi, R., Roldán-Ruiz, I., Reheul, D.: In situ quantification of forage grass root biomass, distribution and diameter cases under two N fertilisation rates. - Plant Soil 411: 409-422, 2017.

Darbyshire, S.J., Warwick, S.I.: Phylogeny of North American Festuca (Poaceae) and related genera using chloroplast DNA restriction site variation. - Can. J. Bot. 70: 2415-2429, 1992.

Dickinson, N.M., Polwart, A.: The effect of mowing regime on an amenity grassland ecosystem: above- and below-ground components. - J. appl. Ecol. 19: 569-577, 1982.

Durand, J.L., Bariac, T., Ghesquière, M., Biron, P., Richard, P., Humphreys, M., Zwierzykowski, Z.: Ranking of the depth water extraction by individual grass plants using natural ${ }^{18} \mathrm{O}$ isotope abundance. - Environ. exp. Bot. 60: 137-144, 2007.

Essad, S.: [Comparative study of reciprocal hybrids of Lolium perenne L. $\times$ Festuca pratensis Huds. and of their progeny.] Ann. Amélior. Plantes 14: 295-308, 1964. [In French]

Fojtik, A.: Methods of grass improvement used at the Plant Breeding Station Hladké Životice. - Genet. Pol. 35A: 25-31, 1994.

Ghesquière, M., Emile, J.C., Jadas-Hécart, J., Mousset, C., Traineau, R., Poisson, C.: First in vivo assessment of feeding value of Festulolium hybrids derived from Festuca arundinacea var. glaucescens and selection for palatability. Plant Breed. 115: 238-244, 1996.

Ghesquière, M., Humphreys, M.W., Zwierzykowski, Z.: Festulolium. - In: Boller, B., Posselt, U.K., Veronesi, F. (ed.): Fodder Crops and Amenity Grasses. Handbook of Plant Breeding. Vol. 5. Pp. 293-316. Springer, New York Dordrecht - Heidelberg - London 2010a.

Ghesquière, M., Humphreys, M.W., Zwierzykowski, Z.: Festulolium Hybrids: Results, Limits and Prospects. - In: Huyghe, C. (ed.): Sustainable Use of Genetic Diversity in Forage and Turf Breeding. Pp. 159-180. Springer, Dordrecht 2010b.

Gymer, P.T., Whittington, W.J.: Hybrids between Lolium perenne and Festuca pratensis. II. Comparative morphology. - New Phytol. 72: 861-865, 1973.

Harper, J., Gasior, F., Mathews, R., Thomas, A., Evans, C., King, J., King, I., Humphreys, M., Armstead, I.: An investigation of genotype-phenotype association in a Festulolium forage grass population containing genome-spanning Festuca pratensis chromosome segments in a Lolium perenne background. PLoS ONE 13: 0207412, 2018.

Humphreys, J., Harper, J.A., Armstead, I.P., Humphreys, M.W.: Introgression-mapping of genes for drought resistance transferred from Festuca arundinacea var. glaucescens into Lolium multiflorum. - Theor. appl. Genet. 110: 579-587, 2005. Humphreys, M.W.: The controlled introgression of Festuca 
arundinacea genes into Lolium multiflorum. - Euphytica 42:105-116, 1989.

Humphreys, M.W., Doonan, J.H., Boyle, R., Rodriguez, A.C., Marley, C.L., Williams, K., Farrell, M.S., Brook, J., Gasior, D., Loka, D., Collins, R.P., Marshall, A.H., Allen, D.K., Yadav, R.S., Dungait, J.A., Murray, P., Harper, J.A.: Root imaging showing comparisons in root distribution and ontogeny in novel Festulolium populations and closely related perennial ryegrass varieties. - Food Energy Security 7: e00145, 2018.

Humphreys, M.W., Ghesquière, M.: Assessing success in gene transfer between Lolium multiflorum and Festuca arundinacea. - Euphytica 77: 283-289, 1993.

Humphreys, M.W., Gasior, D., Leśniewska-Bocianowska, A., Zwierzykowski, Z., Rapacz, M.: Androgenesis as a means of dissecting complex genetic and physiological controls: selecting useful gene combinations for breeding freezingtolerant grasses. - Euphytica 158: 337-345, 2006a.

Humphreys, M.W., Harper, J.: Festulolium loliaceum, an understudied natural UK grass hybrid species that may provide benefits to UK grasslands withstanding the onsets of climate change. - Crop wild Relative 6: 7-9, 2008.

Humphreys, M.W., MacLeod, C.J.A., Whalley, W.R., Turner, L.B., Farrell, M.S., Ghesquière, M., Haygarth, P.M.: Designing grass cultivars for droughts and floods. - In: Barth, S., Milbourne, D. (ed.): Breeding Strategies for Sustainable Forage and Turf Grass Improvement. Pp. 171-179. Springer, Dordrecht - Heidelberg - London - New York 2012.

Humphreys, M.W., O’Donovan, S.A., Farrell, M.S., Gay, A.P., Kingston-Smith, A.H.: The potential of novel Festulolium ( $2 n$ $=4 x=28$ ) hybrids as productive, nutrient-use-efficient fodder for ruminants. - Food Energy Security 3: 98-110, 2014a.

Humphreys, M.W., O’Donovan, G., Sheehy-Skeffington, M.: Comparing synthetic and natural grasslands for agricultural production and ecosystem service. - Grassl. Sci. Eur. 19: 215229, 2014b.

Humphreys, M.W., Pašakinskiene, I.: Chromosome painting to locate genes for drought resistance transferred from Festuca arundinacea into Lolium multiflorum. - Heredity 77: 530-534, 1996.

Humphreys, M.W., Thomas, H.M., Morgan, W.G., Meredith, M.R., Harper, J., Thomas, H., Zwierzykowski, Z. Ghesquière, M.: Discriminating the ancestral progenitors of hexaploid Festuca arundinacea using genomic in situ hybridisation. Heredity 75: 171-174, 1995.

Humphreys, M.W., Yadav, R.S., Cairns, A.J., Turner, L.B., Humphreys, J., Skøt, L.: A changing climate for grassland research. - New Phytol. 169: 9-26, 2006 b.

Jauhar, P.P.: Genetic regulation of diploid-like chromosome pairing in the hexaploid species, Festuca arundinacea Schreb. and F. rubra L. (Gramineae). - Chromosoma 52: 363-382, 1975.

Jauhar, P.P.: Cytogenetics of the Festuca-Lolium complex. - In Frankel, R., Grossman, M., Linskens, H.F., Maliga, P., Riley, R. (ed.): Monographs on Theoretical and Applied Genetics. Vol. 19. Springer Verlag, Berlin - Heidelberg - New York 1993.

Jenkin, T.J.: The artificial hybridisation of grasses. - Welsh Plant Breed. Sta. Bull. Ser. H. 2: 5-34, 1924.

Jenkin, T.J.: Interspecific and intergeneric hybrids in herbage grasses. Initial crosses. - J. Genet. 28: 205-264, 1933.

Jokś, W., Zwierzykowski, Z., Jokś, E., Nowak, T.: Agronomic value of Festulolium (Festuca pratensis $\times$ Lolium multiflorum) strains. - In: Reheul, D., Ghesquiere, A. (ed.): Breeding for Quality. Pp. 265-266. EUCARPIA Fodder Crops, Brugge 1995.

Kamau, S., Belanche, A., Davies, T., Rees-Stevens, P.,
Humphreys, M., Kingston-Smith, A.: A route to decreasing N pollution from livestock: Use of Festulolium hybrids improves efficiency of $\mathrm{N}$ flows in rumen simulation fermenters. - Food Energy Security DOI: 10.1002/fes3.209, 2020.

Kell, D.B.: Breeding crop plants with deep roots: their role in sustainable carbon, nutrient and water sequestration. - Ann. Bot. 108: 407-418, 2011

Kole, C., Muthamilarasan, M., Henry, H., Edwards, S., Sharma, R., Abberton, M., Batley, J., Bentley, A., Blakeney, M., Bryant, J., Cai, H., Cakir, M., Leland, C., Cockram, J., de Oliveira, A., de Pace, C., Dempewolf, H., Ellison, S., Gepts, P., Greenland, A., Hall, A., Hori, K., Hughes, S., Humphreys, M., Iorizzo, M., Ismail, A., Marshall, A., Mayes, S., Nguyen, H., Ogbonnaya, F., Ortiz, R., Paterson, A., Simon, P., Tohme, J., Tuberosa, R., Valliyodan, B., Varshney, R., Wullschleger, S., Yano, M., Prasad, M.: Application of genomics-assisted breeding for generation of climate reslient crops: progress and prospects. - Front. Plant Sci. 6: 563, 2015.

Kopecký, D., Harper, J., Bartoš, J., Gasior, D., Vrána, J., Hřibová, E., Boller, B., Ardenghi, N.M.G., Šimoníková, D., Doležel, J., Humphreys, M.W.: An increasing need for productive and stress resilient Festulolium amphiploids: what can be learnt from the stable genomic composition of Festuca pratensis subsp. apennina (De Not.) Hegi? - Front. environ. Sci. 4: 66, 2016.

Kopecký, D., Baert, J., Barth, S., Bartoš, J., Černoch, V., Doležel, J., Grogan, D., Harper, J., Humphreys, M., Książczyk, T., Øtrem, L., Paszkowski, E., Sokolovič, D., Zwierzykowski, Z., Ghesquière, M.: Genotyping of Festulolium cultivars involved in EUCARPIA multi-site trial using DarT markers and GISH. - In: Brazauskas, G., Statkevičiutè, G., Jonavičienė, K. (ed.): Breeding Grasses and Protein Crops in the Era of Genomics. Pp 155-159. https://doi.org/10.1007/978-3-319-89578-9_28 2018.

Kopecký, D., Loureiro, J., Zwierzykowski, Z., Ghesquière, M., Doležel, J.: Genome constitution and evolution in Lolium $\times$ Festuca hybrid cultivars (Festulolium). - Theor. appl. Genet. 113: 731-742, 2006.

Kopecký, D., Lukaszewski, A.J., Doležel, J.: Genomic constitution of Festulolium cultivars released in the Czech Republic. - Plant Breed. 124: 454-458, 2005.

Kopecký, D., Šimoníková, D., Ghesquière, M., Doležel, J.: Stability of genome composition and recombination between homoeologous chromosomes in Festulolium (Festuca $\times$ Lolium) cultivars. - Cytogenet. Genome Res. 151: 106-114, 2017.

Kubota, A., Akiyama, Y., Ueyama, Y.: Variability of genomic constitutions of Festulolium (Festuca $\times$ Lolium) within and among cultivars. - Grassl. Sci. 61: 15-23, 2015.

Lewis, E.J., Humphreys, M.W., Caton, M.P.: Disomic inheritance in Festuca arundinacea Schreb. - Z. Pflanzenüchtg. 84: 335341, 1980.

Lewis, E.J., Tyler, B.F., Chorlton, K.H.: Development of LoliumFestuca Hybrids. - Rep. Welsh Plant Breed. Sta. 1973.

Li, Y., Liu, Y., Harris, P., Sint, H., Murray, P.J., Lee, M.R.F., Wu, L.: Assessment of soil water, carbon and nitrogen cycling in reseeded grassland on the North Wyke Farm Platform using a process based model. - Sci. total Environ. 603: 27-37, 2017.

Loureiro, J., Kopecký, D., Castro, S., Santos, C., Silveira, P.: Flow cytometric and cytogenetic analyses of Iberian Peninsula Festuca spp. - Plant. Syst. Evol. 269: 89-105, 2007.

MacLeod, C.J.A., Humphreys, M.W., Whalley, R., Turner, L., Binley, A., Watts, C.W., Skot, L., Joynes, A., Hawkins, S., King, I.P., O'Donovan, S., Haygarth, P.M.: A novel grass hybrid to reduce flood generation in temperate regions. Natur. Sci. Rep. 3: 1683, 2013. 
Malik, C.P., Thomas P.T.: Meiosis in the intergeneric hybrid between Lolium multiflorum $(2 n=14)$ and Festuca arundinacea $(2 n=70)$ and its amphiploid $(2 n=84) .-\mathrm{Z}$. Pflanzenzücht. 55: 81-94, 1966.

Marshall, A.H., Collins, R.P., Humphreys, M.W., Scullion, J.: A new emphasis on root traits for perennial grass and legume varieties with environmental and ecological benefits. - Food Energy Security 5: 26-39, 2016.

Muhandiram, N.P.K., Humphreys, M.W., Fychan, R., Davies, J.W., Sanderson, R., Marley, C.L.: Do agricultural grasses bred for improved root systems provide resilience to machinery-derived soil compaction? - Food Energy Security 2020 (in press)

Mwendia, S., Maass, B.L., Njenga, D., Notenbaert, A.M.O.: Perennial ryegrass and novel Festulolium forage grasses in the tropical highlands of Central Kenya: preliminary assessment. - Trop. Grassl. 7: 234-243, 2019.

Nekrošas, S., Sliesaravičius, A., Dapkiene, R.: [Festulolium variety 'Punia'.] - Žemdirbystė (Agriculture) 50: 203-208, 1995. [In Lithuanian].

Nekrošas, S., Kemešytè, V.: Breeding of ryegrass and Festulolium in Lithuania. - Žemdirbyste (Agriculture) 94: 29-39, 2007.

Netzband, K.: Breeding of tetraploid Festulolium fodder grasses with different maturity. - In: den Nijs, A., Elgersma, A. (ed.): Fodder Crops Breeding: Achievements, Novel Strategies and Biotechnology. Pp. 47-48. EUCARPIA Fodder Crops, Wageningen 1991.

Newman, E.L., Ritz, K., Jupp, P.: The functioning of roots in the grassland ecosystem. - Aspects appl. Biol. 22: 263-269, 1989.

O'Donovan, S.A.: Transmission and expression of Festuca arundinacea var glaucescens traits into Lolium spp. for improved efficiency of protein use by ruminants. - $\mathrm{PhD}$ Thesis, Aberystwyth University, Aberystwyth 2015.

Østrem, L., Volden, B., Larsen, A.S.: Morphology, dry matter yield and phenological characters at different maturity stages of $\times$ Festulolium compared with other grass species. - Acta agr. scand. - Sect. B 63: 531-542, 2013.

Pašakinskienè, I., Jones, R.N.: Challenging genome integrity. Biologija 1: 3-9, 2003.

Pedersen, J.F., Eizenga, G.C., Burrus, P.B., Jr.: Registration of KY-2N56 tall fescue germplasm. - Crop Sci. 30: 1163, 1990.

Powell, H.G., Fychan, R., Marley, C.L., McCalman, H.M., Humphreys, M.W.: Research and farming working together to develop grassland varieties resilient to extreme weather events to mitigate climate change. - Grassl. Sci. Eur. 23 (Sustainable meat and milk production from grasslands): 1013-1015, 2018.

Rapacz, M., Gąsior, D., Zwierzykowski, Z., LeśniewskaBocianowska, A., Humphreys, M.W., Gay, A.P.: Changes in cold tolerance and the mechanisms of acclimation of photosystem II to cold hardening generated by anther culture of Festuca pratensis $\times$ Lolium multiflorum cultivars. - New Phytol. 162: 105-114, 2004.

Shaw, R.K.: Effects of gene transfer from Festuca to Lolium on plant-mediated proteolysis. - PhD Thesis, Aberystwyth University, Aberystwyth 2006.

Soreng, R., Terrell, E.: Taxonomic notes on Schedonorus, a segregate genus from Festuca or Lolium, with a new nothogenus $\times$ Schedololium, and new combinations. -
Phytologia 83: 85-88, 1997.

Stammers, M., Harris, J., Evans, G.M., Hayward, M.D., Forster, J.W.: Use of random PCR (RAPD) technology to analyse phylogenetic relationships in the Lolium/Festuca complex. Heredity 74: 19-27, 1995.

Stapleton, R.G., Davies, W.: Ley Farming. - Faber and Faber Ltd., London 1948.

Thomas, H., Evans, C., Thomas, H.M., Humphreys, M.W., Morgan, W.G., Hauck, B.D., Donnison, I.: Introgression, tagging and expression of a leaf senescence gene in Festulolium. - New Phytol. 137: 29-34, 1997.

Thomas, H., Humphreys, M.O.: Progress and potential of interspecific hybrids of Lolium and Festuca. - J. agr. Sci. 117: $1-8,1991$.

Thomas, H.M., Morgan, W.G., Meredith, M.R., Humphreys, M.W., Thomas, H., Leggett, J.M.: Identification of parental and recombined chromosomes in hybrid derivatives of Lolium multiflorum $\times$ Festuca pratensis by genomic in situ hybridization. - Theor. appl. Genet. 88: 909-913, 1994.

Torrecilla, P., Catalán, P.: Phylogeny of broad-leaved and fineleaved Festuca lineages (Poaceae) based on nuclear ITS sequences. - Syst. Bot. 27: 241-251, 2002.

Turner, L.B., Cairns, A.J., Armstead, I.P., Thomas, H., Humphreys, M.W., Humphreys, M.O.: Does fructan have a functional role in physiological traits? Investigation by quantitative trait locus mapping. - New Phytol. 179: 765-775, 2008.

Wilkins, P.W., Humphreys, M.O.: Progress in breeding forage grasses for temperate agriculture. - J. agr. Sci. 140: 129-150, 2003.

Yamada, T., Forster, J.W., Humphreys, M.W., Takamizo, T.: Genetics and molecular breeding in Lolium/Festuca complex. - Grassl. Sci. 51: 89-106, 2005.

Zwierzykowski, Z., Jokś, W., Naganowska, B.: Potential of tetraploid Festulolium (Festuca pratensis $\times$ Lolium multiflorum). - In: Rognli, O.A., Solberg, S., Schjeldrup, I. (ed.): Breeding Fodder Crops for Marginal Conditions. Pp. 299-300. Kluwer Academic Publishers, Dordrecht 1994.

Zwierzykowski, Z., Kosmala, A., Zwierzykowska, E., Jones, N., Jokś, W., Bocianowski, J.: Genome balance in six successive generations of the allotetraploid Festuca pratensis $\times$ Lolium perenne. - Theor. appl. Genet. 113: 539-547, 2006.

Zwierzykowski, Z., Tayyar, R., Brunell, M., Lukaszewski, A.J.: Genome recombination in intergeneric hybrids between tetraploid Festuca pratensis and Lolium multiflorum. - J. Hered. 89: 324-328, 1998.

Zwierzykowski, Z., Zwierzykowska, E., Taciak, M., Jones, N., Kosmala, A., Krajewski, P.: Chromosome pairing in allotetraploid hybrids of Festuca pratensis $\times$ Lolium perenne revealed by genomic in situ hybridization (GISH). Chromosome Res. 16: 575-585, 2008.

Zwierzykowski, Z., Zwierzykowska, E., Taciak, M., Kosmala, A., Jones, N., Zwierzykowski, W., Książczyk, T., Krajewski, P.: Genomic structure and fertility in advanced generations of breeding populations derived from the allotetraploid Festuca pratensis $\times$ Lolium perenne. - Plant Breed. 130: 476-480, 2011. 